University of Nebraska - Lincoln

DigitalCommons@University of Nebraska - Lincoln

The Nebraska Educator: A Student-Led Journal Department of Teaching, Learning and Teacher

Education

Spring 10-5-2021

\title{
Triangulating Research that Focuses on Decolonizing and Race- Based Educational Theories
}

\author{
Beth Dotan \\ University of Nebraska-Lincoln, bdotan@huskers.unl.edu
}

Follow this and additional works at: https://digitalcommons.unl.edu/nebeducator

Part of the Curriculum and Instruction Commons, Disability and Equity in Education Commons, Educational Methods Commons, Scholarship of Teaching and Learning Commons, and the Teacher Education and Professional Development Commons

Dotan, Beth, "Triangulating Research that Focuses on Decolonizing and Race-Based Educational Theories" (2021). The Nebraska Educator: A Student-Led Journal. 58.

https://digitalcommons.unl.edu/nebeducator/58

This Article is brought to you for free and open access by the Department of Teaching, Learning and Teacher Education at DigitalCommons@University of Nebraska - Lincoln. It has been accepted for inclusion in The Nebraska Educator: A Student-Led Journal by an authorized administrator of DigitalCommons@University of Nebraska - Lincoln. 


\title{
Triangulating Research that Focuses on Decolonizing and Race-Based Educational Theories
}

\author{
Beth Dotan \\ Department of Teaching, Learning, and Teacher Education \\ University of Nebraska-Lincoln
}

\begin{abstract}
The normalization of white cultural and societal educational standards often produce uniform consumers of knowledge. In an effort to seek modification from conventional educational belief systems, this literature review looks at a collection of critical, race-based, and anti-/ de-colonial epistemologies and challenges traditions of inquiry. The research: 1) articulates how national culture perpetuates divisiveness through race and racism in colonized American society and institutions, 2) contemplates the amalgamation of Jewishness and whiteness, and 3) considers utilizing critical theory and social justice views to decolonize educational methodologies as a path to implement change. Historical context and the diverse array of scholarship on critical theories using the narratives of race-based epistemologies in this literature review suggest a directional shift to center marginalized voices and redefine how knowledge is acquired in our systems.
\end{abstract}

Keywords: decolonizing, race-based educational theories, critical theories, Jewish identity, whiteness studies, race-based epistemologies, race, racism 


\section{THE NEBRASKA EDUCATOR, VOLUME 6}

'Children are not future people, because they are people already...Children are people whose souls contain the seeds of all those thoughts and emotions that we possess. As these seeds develop, their growth must be gently directed.'10

\section{Dr. Janusz Korczak}

In an effort to seek a modification from a conventional white educational belief system, this literature review looks at critical, race-based, and anti-/ de-colonial epistemologies and challenges traditions of inquiry, in particular from the author's position at the intersection of whiteness and Jewishness. Although only a fraction of the extant literature on critical theories is included in this review, the collection can inspire educators to scrutinize what counts as knowledge (Delgado Bernal, 2002). The scholarship requires the reader to examine who is cultivating knowledge and who benefits from that knowledge (Berry, Summer-Fall, 2010; Berry, 2017; Delgado Bernal, 2002; Dixson et al., 2018; Patel, 2016; Tejeda-Espinoza, 2003). The research exposes how the normalization of While educational standards often produce uniform consumers of knowledge.

Polish and Jewish pedagogue Janusz Korczak's declaration that "children are not future people" (Lewowicki, T., 1994, p. 4) infers that children are individuals with rights beyond racial identity and socioeconomic status. At the turn of the last century, Korczak adhered to a progressive educational model that put the child and his/her engagement with the world as central to learning. He grounded his work in vilifying oppression of children to ensure the survival of their agency, dignity, and life. Korczak's legacy is vast, but he is most significantly remembered for the relentless care and respect of hundreds of children orphaned in the Warsaw Ghetto. In August, 1942 Korczak, along with 200 children and staff from his orphanage were forced to gather in the ghetto, transported by train, and murdered upon arrival at the Treblinka

10 Janusz [Korczak], 'Rozwòj idei milosci blizniego w xix wieku [Development of the love-thy-neighbour ideal in the nineteenth century]', Czytelnia dla Wszystkich [Universal Reader], no. 52, 1899 as cited in Lewowicki, T. 1994). 
THE NEBRASKA EDUCATOR, VOLUME 6

killing center. Through my personal work in Holocaust education, I have interacted and honored his lasting educational pedagogy. There is a profundity to Korczak's philosophical principles and foresight that energized my personal and educational values. Consequently, only upon validation of the introductory statement by Korczak, do I see the work of critical theorists succeeding in repudiating white institutionalism or placing a wedge in reconstructing perpetual educational disparities (Berry, 2017; Delgado Bernal, 2002, Ladson-Billings \& Tate, 1995; Omi \& Winant, 2014; Patel, 2016; Scheurich \& Young, 1997).

This literature review intends to triangulate the research and explore integrating decolonizing and race-based educational theories into teaching methodologies. The review 1) articulates how national culture perpetuates divisiveness through race and racism in colonized American society and institutions, 2) contemplates the amalgamation of Jewishness and whiteness, and 3) considers utilizing critical theory and social justice work to decolonize educational methodologies as a path to implement change. Through this process, I aim to establish clarity from my position as a Jewish female educator working in Holocaust Education and gain insight from diverse narratives that might inform appropriate cultural responsiveness toward future social justice work (Ladson-Billings \& Tate, 1995 Tejeda \& Espinoza, 2013).

\section{The Deconstruction of Race and the Impact on Colonized Hierarchy}

The first set of articles deconstructs the concept of race through its historical development, illuminating, particularly in the US, how the interpretation of the term over time has led to the segregation of peoples and the establishment of white hierarchy. Golash-Boza, (2019) specifies race as a modern social construction "referring to a group of people that share physical and cultural traits" (p.3). The term race and its interpretation as an idea is a "modern" construction, which can be tied to religious turmoil among European colonialists who regarded 


\section{THE NEBRASKA EDUCATOR, VOLUME 6}

their humanity as superior to "unredeemable" indigenous peoples (Golash-Boza, 2019; Omi \& Winant, 2014; Smedley, 2007). As a result of racial distinctions, "the expropriation of property, the denial of political rights, the introduction of slavery and other forms of coercive labor, as well as outright extermination, all presupposed a worldview which distinguished Europeans... from 'others"” (Omi \& Winant, 2014, p. 3). Society continues to make race and its historical interpretations normalized as a term, an idea, an ideology, and a theory.

From a historical perspective, Golash-Boza (2019) explains that race as an ideology was not a consideration among ancient people due to amicable, intellectual, and economic interactions and contributions among societies. Racialized classifications were later formulated simultaneously with emerging religious discrimination during the Inquisition in the $15^{\text {th }}$ century. Emerging concepts to distinguish human differences in Europe later equated to radical ideas that racial classifications could be based on 'purity of blood.' (Smedley, 2007; Golash-Boza, 2019). The literature provides an historical overview of Northern European enslavement, including descriptions of encounters with American Indigenous peoples and recollections of Spanish conquests. Along with the advance to occupy lands, the belief in manifest destiny (justified expansion in the Americas) perpetuated slavery. Additional laws and regulations were imposed upon multiple groups of people as reinforcement of white control. The brutality of the events accompanying land possession posited power and superiority in the drive to control and create race differentiations (Golash-Boza, 2019; Ladson-Billings \& Tate, 1995; Omi \& Winant, 2014; Smedley, 2007).

The invention of race and racial identity is one of the tragic outcomes of this corrupt history of seized lands. Smedley (2007) suggests that "race is a cultural construct, ...[that] should be analyzed as a social/cultural reality that exists in a realm independent of biological or 
THE NEBRASKA EDUCATOR, VOLUME 6

genetic variation" (p. 1, emphasis added). The historical accounts within the literature include additional discussion from Golash-Boza (2019) and Omi \& Winant (2014) regarding established scientific techniques from the $19^{\text {th }}$ and $20^{\text {th }}$ centuries that attempted to lay a foundation suggesting that distinguishable traits are inherent to the various races. (Smedley, 2007). Anthropologist Franz Boas refuted this scientific thought and others rejected the idea that race and culture are connected biologically (Omi and Winant, 2014). The impact of the attempts to scientifically identify categories of human beings resulted in dangerous presuppositions, namely that racism is "the belief that races are populations whose physical differences are linked to significant cultural and social differences within a hierarchy and the practice of subordinating races believed to be inferior" (Golash-Boza, 2013, p. 3). Despite Boas and others debunking the notion of a biological structure for race, racism became a social byproduct employed as a tool to enforce power and classification within white supremacy. One of the most extreme examples of race as a biological phenomenon to justify the elimination of "inferior" peoples is that of Hitler and the National Socialists' racial ideology that led to the murder of six million Jews. Genocidal practices throughout history have been driven by the misdirected concepts of race and racism and are deeply embedded within society today.

The historical foundation of race has allowed for prejudices to exist in a US culture that tolerates stereotyping and categorization. (Omi \& Winant, 2014). These inferences are often determined and redefined based on the interest of the dominant culture or group. There is overlap in the ideals of ethnicity, class, and nation (Ladson-Billings, 1995), at times even confusing within said cultural groups. ${ }^{11}$ Golash-Boza (2019) differentiates ethnicity from race as a group

11 Omi and Winant (2014) reference the unsuccessful lawsuit of Susie Guillory Phipps, 1982-83, to change her racial designation in her birth certificate from "black" to "white" in a challenge to racial classification and identity. (p. 3) 


\section{THE NEBRASKA EDUCATOR, VOLUME 6}

sharing history, culture, and kinship (Golash-Boza, 2019). Although the terms may occasionally be interpreted similarly, individuals self-identify within ethnic groups, while racial groups are externally established and imposed on a group by others usually outside of the group (GolashBoza, 2019). The interpretations remain complex.

The long and difficult history of race and racialized issues as an ideological, social construct is today evaluated within educational theories. Ladson-Billings and Tate (1995) began to theorize race in education through Critical Race Theory as a means to understand school inequity for non-white students. Their ground-breaking research was based on three positions that reflect the racial ideologies we have seen in the historical component of this literature review:

1. Race is a significant factor in determining inequity in the US

2. US society is based on property rights

3. The intersection of race and property creates an analytic tool to understand social (and, consequently, school) inequity (Ladson-Billings and Tate, 1995, p. 48).

Ladson-Billings and Tate (1995) utilized this research to push back against the ideological construct of race by using CRT as a tool for change. It might be said that they opened the door for future educational researchers, such as Berry, hooks, and Delgado Bernal, through discussion that "challenges the dominant paradigm of ethnicity" (p.50) and institutional racism (Scheurich \& Young, 1997). They advanced the narrative to the forefront through a deep examination of issues, such as the assumptions about civil rights today or the multiple truths of multiculturalism. Not unlike Theodorea Berry (2017) who integrated the inquiry of DeBois and Woodson into her research to center voices of historical narrative against issues of race inequity, Ladson-Billings and Tate (1995) turned to leading Black scholars "to uncover or decipher the social-structural 


\section{THE NEBRASKA EDUCATOR, VOLUME 6}

and cultural significance of race in education" (p. 50). Utilizing narrative reflects Delgado’s (1989) method to confront imposed structures and choose frameworks from our own experiences.

Ladson-Billings and Tate's (1995) main concern was to broaden the perspective for those who scrutinize racial inequities through educational research and critical thinking with voices that have been silenced. In their paper's third position on the intersection of race and property, Ladson-Billings and Tate (1995) confront what Scheurich \& Young (1997) consider "civilization racism" (p. 7). The historical development of race and racial ideology characterizes how white dominance has employed land rights, occupied the position of social and cultural privilege, and claimed the status of economic advantage. According to Omi and Winant (2014) "thinking of race strictly as an ideological construct denies the reality of a racialized society and its impact on 'raced' people in their everyday lives"' (p. 48).

The collection of literature in this paper introduces a variety of researchers whose methodologies push marginalization and racism away from the periphery by centering raced epistemologies as critical ways of knowing (Anzaldúa, 1987; Anzaldúa, 2009; Bhattacharya, 2015; Chávez, 2012; Delgado Bernal, 2002; Ladson-Billings \& Tate, 1995). These authors and others highlight how the intersection of race ideology and hegemonic forms of ideology shape identity in a hierarchal, white educational system that relentlessly replicates discrimination and assimilationism (Chavez, 2012) that skews student perceptions of the world to one a coherent perspective. Methods of navigating knowledge intake only from a white perspective do not nourish growth in learners but instead stifles it. This perspective is particularly true within dominant white groups and institutions (Atunes, 2017; Berry, 2010; Delgado Bernal, 2002; 2018, Golash-Boza, 2019; hooks, n.d.; Jupp et al., 2018; Jupp, 2020; Kohli, 2008; Matias, 2016; 


\section{THE NEBRASKA EDUCATOR, VOLUME 6}

Morales et al., 2019; Omi \& Winant, 2014; Picower, 2009). Only by studying the varied voices guiding Critical Race Theory (CRT), Critical Race Feminism (CRF), LatCrit, and others can researchers value the agency of women, people of color, and individuals of diverse ethnic entities including the Jewish community. Exposure to the work of these scholars, who create change through rigorous collaborative effort, provides a standard for the classroom educator and ultimately for the diversity in which students can learn and understand the world.

\section{Jewishness, Whiteness and Where They Might Meet}

Familiarity with the race-based theoretical literature mentioned above is formative to acknowledge how racist divisions became embedded in traditional theories of Western institutionalism, particularly within the educational system. The forthcoming section of reviewed literature will look at the Jewish community as a cultural and racialized entity. We do this with caution, as drawing parallels and comparisons of various racialized groups can contribute to unwarranted sensitivities. This author acknowledges that the Jewish experience in the United States is not comparable to that of other groups. Still, the intersection of the history of the Jews and aspired success as a cultural group presents countless issues.

As an American Jewish woman and Holocaust educator, it has been essential to explore the literature further to confront the realities of those "othered" within the dominant white culture. McIntosh (1988) noted that "as a white person, I realized I had been taught about racism as something that puts others at a disadvantage but had been taught not to see one of its corollary aspects, white privilege, which puts me at an advantage" (p. 29-30). Critical White Studies (CWS) exposes a deeper understanding of how the white community leverages race and racism to maintain superiority (Jupp, 2020). There are numerous examples of how the white Christian community standardized rules of acceptance, discriminating against Jews and others in numerous 


\section{THE NEBRASKA EDUCATOR, VOLUME 6}

ways, for example quietly blocking membership in places such as country clubs, denying access to housing, or creating quota systems at higher institutes of education. These were some of the ways that the white population maintained superiority.

Historically, Jews have been the victims of hatred and displacement caused by virulent antisemitism. Despite a reprieve from discrimination and persecution in Poland-Lithuania and the Iberian Peninsula in different historical periods, the Jew was considered an outsider even in kingdoms where they had been invited to emigrate. Jews settled in numerous European countries, yet they were consistently considered "non" white, as their ancestry was diasporic. In $15^{\text {th }}$ century Spain, religious discrimination was instigated by edict, ultimately establishing European racist ideologies before monarchical exploration to new territories and later colonialism (Smedley, 2007; Golash-Boza, 2019). When not expelled or murdered, Jews continued to be foreigners in adopted lands. How is Jewish "otherness" manifested in more recent cultural history?

One study based on CRT and CWS methodologies identified hegemonic responses among white preservice teachers working with students of color. In the analysis from the narrative of a Jewish student, Picower (2009) deduces that "one who has experienced negative remarks because of her religious affiliation, caused her to minimize the idea of racial discrimination and, in particular, to deny her identification as a member of the dominant racial group" (p. 201). We look closer at literature addressing the complexity and intersectionality of whiteness and Jewishness exemplified in the second-wave movement of CWS that considers a variety of social and historical issues to analyze data (Jupp, 2020). As evident in Picower's (2009) research, Jewishness can maintain an unclear status within American society yet can be dismissed under the guise of whiteness. 


\section{THE NEBRASKA EDUCATOR, VOLUME 6}

To better understand the positionality of whiteness and Jewishness, we will look at two pieces of literature. One, an article by Schraub (2019), titled "White Jews: An Intersectional Approach," and components from Goldstein's (2006) book titled The Price of Whiteness: Jews, Race, and American Identity. The review of these resources will look at highlights that address the issues of being Jewish in white America historically, the ramifications of Jewishness as a subgroup within an ethnic identity, and concerns regarding racism and antisemitism today.

The literature suggests that as race theories develop, those who confront the traditional and colonialist methodologies often find themselves at an intersection between cultural identity and socialized classifications. The Price of Whiteness (Goldstein, 2006) discusses the various developments in the integration of the Jewish community in the US since the colonial period. For the sake of this review, the focus will be on those chapters that specifically address Jewishness in its relation to the white community. A parallel theme, which will not be explored at this time, investigates how Jews interacted with the African American community.

Various periods mark the changes for the Jewish community throughout their integration into American society. Goldstein (2006a) discusses how the historical complexities of Jewishness in a racialized society must continue to be navigated amidst nuanced prejudices that have never fully dissipated. In a colonized society where racial ideology identifies people as either "white" or "non-white," this binary interplay is motivated by social, economic, and political forces (Omi \& Winant, 2014). As with other racially designated groups, this has often created misconceptions even within the Jewish community itself, particularly as immigration waves affected their status.

Up until the later part of the $19^{\text {th }}$ century, Jews had immigrated mainly from Central Europe, integrating into American life and acculturating readily to customs and society. This 
THE NEBRASKA EDUCATOR, VOLUME 6

acceptance allowed them to identify as a religious community in a way they had not experienced in recent history (Goldstein, 2006a). While socially accepted, increased interactions and economic opportunities remained available until the end of the Civil War. But later, new definitions regarding group identity both from within and without the community emerged, as did restrictions for Jews in social and civic organizations. During this time, racial terms for immigrants and groups of color were becoming part of the American discourse. Jews began to subscribe as a "race" to maintain acceptance in the non-Jewish world and were considered part of the white community (Goldstein, 2006a).

At the turn of the $20^{\text {th }}$ century, with increased immigration, industrialization, and white America's concern for renewed supremacy in a changing society, Jews began questioning whether to continue to identify "racially" (Goldstein, 2006c). Along with other newcomers, Eastern European Jewish immigration to the US increased exponentially, changing the assimilated Jewish community's landscape. Despite their desire to be integrated within the majority, Jews also wanted to maintain their religiosity. But, in the 1910 Census, "Jews feared that the government's adoption of a 'Hebrew' classification might be the first step toward their eventual exclusion from the rights of white American citizens" (p. 109) (See Table \#1). Even in 2019, the federal government was still attempting to define the status of Jews in America. ${ }^{12}$

\footnotetext{
12 There is still identification discussion today. An Executive Order (December 11, 2019) on antisemitism did two primary things:

- "It shall be the policy of the Executive Branch" to enforce Title VI of the Civil Rights Act of 1964, which prohibits discrimination in programs receiving federal funding, "against prohibited forms of discrimination rooted in antisemitism as vigorously as against all other forms of discrimination; prohibited by the statute"

- "The Executive Order does not define Jews as a nationality, but it prohibits discrimination against Jews, Muslims, Sikhs, and members of other religious groups when the discrimination is based on the group's actual or perceived shared ancestry or ethnic characteristics - or when the discrimination is based on actual or perceived citizenship or residence in a country whose residents share a dominant religion or a distinct religious identity."

Retrieved from: https://www.adl.org/resources/backgrounders/the-presidents-executive-order-on-antisemitism-frequently-asked-questions
} 
THE NEBRASKA EDUCATOR, VOLUME 6

By the end of WWII, increased American nationalism under the Roosevelt administration embraced Jews and other groups into the national culture. Jews were integrated into the military, whereas other groups, such as African Americans, were still divided as segregated units. Changes regarding race and ethnicity were distinguished, mainly to push against Hitler's racial, ideological theories (Goldstein, 2006d). As civil rights and struggles for minoritized groups pressed forward, the Jews, for the most part, had integrated into the fabric of America. African Americans saw them as part of the "racist power structure" (Goldstein, 2006e, p. 213). Goldstein presents the paradox of Jews in America:

“Jews' impressive economic mobility and their high degree of integration into universities, neighborhoods, professions and other central institutions of American life made it hard for them to claim the status of an 'oppressed minority' in anything other than a faint historical sense. Yet the more distant they became from their minority social status; the more Jews felt the need to highlight their difference from white society" ( $p$. 213).

This degree of integration into the larger American society, along with a complicated Jewish history, including the Holocaust, leaves Jews in a precarious social and ideological position. At this juncture, Schraub's (2019) article on the intersectionality of Jewishness and whiteness provides clarity on Jews as a minority in America.

The point of contention that lies at the heart of Schraub's (2019) discussion is, "What does 'Whiteness' do to 'Jewishness"' (p. 379)? He argues that intersecting the concepts of "Whiteness" and "Jewishness" when investigating Jews as a minority group in America provides a framework to assess political underpinnings and identify issues of Jewish in/equality (in particularly antisemitism) that might otherwise be unseen or misunderstood. (See Table \#2a) In 


\section{THE NEBRASKA EDUCATOR, VOLUME 6}

Crenshaw's (1991) case on the intersection of race and sex, Black Woman were marginalized by white women and African American men, as well as by an institution. Identifying the issues through the tool of intersectionality provides perspectives to see raced oppression differently (Schraub, 2019). The deep-rooted ideologies of the American binary "white" and "non-white" racial formation (Omi and Winant, 2014) as discussed earlier, are perpetuated within our socialized culture. Society responds through a color-blind lens, normalizing only whiteness. Therefore, negotiating the points of intersection attempts to reveal that which is not apparent. This is true also in educational settings.

European Jewish immigration and the historical integration into American society, as revealed in Goldstein's (2006) book, leaves little doubt that Jews in this country are considered white, yet still "raced" in certain situations. Schraub (2019) discusses how interconnecting these two terms "White Jew" can sometimes amplify forms of antisemitic assertions in some circumstances. Antiracism discourse works to "neutralize the power of whiteness, but Jewishness combined with whiteness can exacerbate the ideas of 'power, domination, or social control' leading to antisemitic tropes" (Schraub, 2019, p. 184). In other words, antiracist language that might be used to raise issue with white power in other racialized situations can be used to minoritize Jews or lead to stereotyped rhetoric about them. In this way, Jews are forced back into a binary system as outsiders and seen as potentially dangerous to the dominant culture. Subsequently, white supremacists play into this threat of Jewish power, cautioning that Jews should not be equated with the white majority. Schraub (2019) articulates concern regarding this formulation of intersectionality. He identifies a gap in the research on "antisemitism in progressive scholarship [linking] contemporary issues of discrimination, oppression, and identity-based marginalization" (p. 382-383). Jewish identity and antisemitism continue to be 
THE NEBRASKA EDUCATOR, VOLUME 6

redefined through current right-supremacy rhetoric that often becomes mainstream. Antisemitic occurrences continue to increase at an alarming level even in the past few years. ${ }^{13}$

On another level, white hegemony becomes an issue for Jewishness in America in the realm of multiculturalism. While Jews are considered among the hegemonic, dominant, white culture, they do separate themselves as a culturally identifiable group (Goldstein, 2006e). Within race-based epistemologies, it might be logical to identify among multicultural circles to better inform other groups about Jewish ethnic, cultural and religious ideals (even as the multicultural movement itself is waning and being redefined through Culturally Relevant and other pedagogical developments) (Ladson-Billings, 1995). Among scholarly researchers, Jewishness collides with whiteness for not being recognized or valued. On the other hand, Jews in the United States are considered white. "Jewishness is seen as adding nothing to a multicultural conversation; it is already implicitly included as part of the hegemonic 'White' conversation... There is no reason to devote any of our time to their particular experience" (Dollinger, 2018, as cited in Schraub, 2019, p.396) (See Table \#2b+c).

Jewish integration into colonized America meant that as light-skinned immigrants, they melded into the new world through acculturation and often at the compromise of Jewish religious convictions or erasure. White codes and laws of acceptance became part of the makeup of white supremacist culture, neutralizing peoples of all kinds along the way. White culture silently dictates the liminal space where Jews have resided to be both "inside" when defined as such and "outside" when unwanted. "The intersectionality of Jews is only being considered white when

\footnotetext{
13 An example of rising antisemitic incidents occurred in a three-month period in 2019: 80 tombstones toppled in the Omaha, Nebraska Jewish cemetery in late October; 100 gravestones desecrated in a Jewish French cemetery on Dec. 6, 2019; three people murdered in a shooting incident in a Kosher market in New Jersey on Dec. 12, $2019 ; 3$ Jewish students attacked at a fraternity in Bloomington, Indiana on Dec. 13, 2019; a synagogue ransacked and the Torah scrolls desecrated in Beverly Hills on Friday, Dec. 13, 2019. Does discourse shift when Jews are the target of racial (or antisemitic) acts?
} 
THE NEBRASKA EDUCATOR, VOLUME 6

issues of antisemitism does not exclude them" (Schraub, 2019, p. 398). People of color equate Jews as part of privilege and the dominant culture, not as a marginalized minority.

\section{Can Race-Based Epistemologies Provide more than a Lens for Color-blindness?}

After articulating the historical definitions of race and examining the blurred intersection of Jewishness and whiteness, we can now explore epistemologies that seek to modify whiteness in educational institutions. The final set of articles in this literature review will look at several female scholars who have contributed to anti- and decolonizing resources to understand how they deepen race-based work through narrative. Through their contributions, one can sift through the layers of the racial ideology embedded within educational epistemologies and consider avenues for action and change.

The narrative literature of women of color requires astute listening to the telling of what it means to be in liminal spaces, as described by Anzaldúa (2009) in La prieta, Chavez (2012) through her Chicana autoethnographic study and Bhattachariya (2015) through vulnerable personal accounts. Berry (2010 \& 2017) also leverages Critical Feminist Theory (CFT) and Africana studies to clarify how to center the voices of those previously not acknowledged within literature and the classroom. In their own way, each woman positions her story to provide a new consciousness of minoritized populations and the strength of self and truth in her own voice.

Anzaldúa (2009) brings the sacred and unspoken liminal space to the forefront and exposes "possibility" through uncomfortable and honest storytelling. The exposure of her soul in La prieta and the systematic, historical foundation she provides to define the mestiza within $L a$ Frontera relays the complexity of life at the Mexican/US borderland and crossroads. In $\mathrm{La}$ Prieta, Anzaldúa (2009) described herself as "a wind-swayed bridge, a crossroads inhabited by whirlwinds. Gloria, the facilitator, Gloria, the mediator, straddling the walls between abysses" 
THE NEBRASKA EDUCATOR, VOLUME 6

(p.45). Anzaldúa further articulates her struggle to balance the spaces between the dominant culture, as a woman of color, and at a continual juncture of varied identities. While there is no comparison to the reality of Gloria Anzaldúa's traumatic life experiences, nor the fraught marginalization of the Latino culture and history in this country, for this author, there are familiar tropes of racial separateness that are reminiscent of Jewish historical experiences.

Chávez (2012) reveals opportunities to position herself of marginalized Chicana spaces to produce autoethnographic testimonios as a vehicle for CRT methodology. Searching for the insight to understand the ideological constructs that drive hegemonic assimilation and silencing (Chávez, 2012), her work narrates personal experiences in white academia and other educational institutions where inequity and racism need to be flushed out. Chávez (2012) references the importance of narrative by quoting Ladson-Billings and Tate (1995) who "describe stories by people of color as a way to 'catalyze the necessary cognitive conflict to jar dysconscious racism' (Ladson-Billings and Tate, 1995, p. 58 as cited by Chávez, 2012, p. 342).

In much the same way, as a woman of color, Bhattacharya (2015) utilizes narrative to decolonize scholarship and to navigate a culture of racial marginalization within the academy. Referring to the use of her storytelling as a vulnerable space to explore inquiry, Bhattacharya's (2015) places of intersectionality provide the platform on which to challenge colonized discourse. Like Chávez, her experiences as a female, brown person have strengthened her determination in discovering and sharing that there are unique ways to imagine and obtain knowledge (Bhattacharya, 2015).

Finally, Berry (2017) notes that Western ideals meet the intersections of Africana Studies with languid enthusiasm. She reminds us that as education has become globally interconnected, it has "become more about Western competition and less about the exchange of ideas" (p. 54). 
THE NEBRASKA EDUCATOR, VOLUME 6

She uses her study to explain how Africana studies is a counter-narrative for social justice, bringing the archetypal "voices of Black, Africa studies' scholars - DuBois, Woodson, and Davis" to enrich the curriculum theory in her work (Berry 2017). She reminds us not only that narrative is critical as cultural enrichment but to remember that "there is more than one way to tell a story... and honor the multiple stories we bring to our learning experiences" (p.63).

Fortunately, increasing new scholarship on critical educational theories continues to expand on the foundations established by those mentioned above. Despite recent political attempts to maintain the status quo of the white establishment in our educational systems, marginalized voices continue to grow stronger. These female scholars lead by example to articulate how the intersection of identity provides a unique epistemology grounded in personal experience and narrative. They substantiate the idea that knowledge stemming from varied places and encounters can interrupt the hegemonic pattern dictating that there is only one way to know.

\section{Conclusion}

Research has exposed how the normalization of While educational standards often produce uniform consumers of knowledge. By clustering a seemingly disparate collection of scholarship, this literature review defined race and racism, explored the historical misconceptions that accompany the author's intersection of Jewishness and whiteness, and investigated race-based and decolonizing educational theories. The goal of presenting these concepts together was to acknowledge that a directional shift in centering marginalized voices might redefine how knowledge is acquired in our educational systems today.

Some researchers have leveraged critical theories to recognize the "intersectionality among whiteness, abuse, and teacher education" (Matias, 2016, p. 196). Matias (2016) explained 


\section{THE NEBRASKA EDUCATOR, VOLUME 6}

that identifying perpetuating theories that deflect whiteness is useful to deconstruct these recurring systems in our institutions and among teachers. Through her study, she implores us to reexamine our behavior and conceptualization of whiteness as we also embrace the differences of people and race. As exemplified in the literature review, methods to counteract sustained theories include introducing narrative and personal historical storytelling into classroom pedagogy.

Once more in my own scholarship, I marvel at the relevance and measures of humanity embraced by $20^{\text {th }}$ century, Polish (and Jewish) pedagogue Janusz Korczak. As we scrutinize the platforms discussed in this review in the $21^{\text {st }}$ century, Korczak questioned how social class, ethnicity, gender, and location impacted children's lives over 100 years ago. "Wading through his intersectionality, he found [that] the source of misery and oppression was often the imbalance of power between the worlds of the adult and the child" (Vucic, 2017, p. 163). A century after Korczak resisted the oppressive power structure he viewed as embedded within the European school system, we recognize these inequities in our own. Our task, therefore, is to continue to cultivate critical methodologies to counter the normalization of white cultural and social educational institutions. 
THE NEBRASKA EDUCATOR, VOLUME 6

\section{References}

Anzaldúa, G. (1987). Chapters 1\&2. Borderlands/La frontera (pp. 1-23). San Francisco, CA: Aunt Lute.

Anzaldúa, G. (2009). La prieta. In A. L. Keating (Ed.), The Gloria Anzaldúa reader (pp. 38-50). Durham, NC: Duke University Press

Bhattacharya, K. (2015). The vulnerable academic: Personal narratives and strategic de/colonizing of academic structures. Qualitative Inquiry, 22(5), 309-321.

Berry, T. R. (2010). Critical race feminism. In K. Kridel (Ed.), Encyclopedia of Curriculum Studies (1), 151-152. Thousand Oaks, CA: Sage.

Berry, T. R. (Summer-Fall, 2010). Engaged pedagogy and critical race feminism. Educational Foundations, 19-26.

Berry, T. R. (2017). The intersections of Africana studies and curriculum theory: A counterWestern narrative for social justice. Journal of Curriculum Theorizing, 32(1), 53-66.

Chavez, M. S. (2012). Autoethnography, a Chicana's methodological research tool: The role of storytelling for those who have no choice but to do critical race theory. Equity \& Excellence in Education, 45(2), 334-348.

Crenshaw, K. (1991). Mapping the margins: Intersectionality, identity politics, and violence against women of color. Standford Law Review, 45(6), 1241-99.

Delgado, R. \& Stefancic, J. (2001). Introduction. Critical Race Theory: An Introduction (pp. 115). New York: New York University Press.

Delgado Bernal, D. (2002). Critical race theory, Latino critical theory, and critical racedgendered epistemologies: Recognizing students of color as holders and creators of knowledge. Qualitative Inquiry, 8, 105-126. 


\section{THE NEBRASKA EDUCATOR, VOLUME 6}

Dictionary of Races or Peoples, (1911), Washington, DC: Government Printing Office, pp. 11-5, 73-74.

Dixson, A. D., James, A., \& Frieson, B. L. (2018). Taking it to the streets. Critical race theory, Participatory research and social justice. In Understanding Critical Race Research Methods and Methodologies, 64-75. doi: 10.4324/9781315100944-6

Golash-Boza, T. M. (2019). Race and racisms: a critical approach. (pp.3-31) New York: Oxford University Press.

Goldstein, E. L. (2006a). Introduction. The price of whiteness: Jews, race, and American identity. (pp.1-8). Princeton, NJ: Princeton University Press.

Goldstein, E. L. (2006b). "Different Blood Flows in our Veins": Race and Jewish Self-Definition in Late-Nineteenth-Century-America. The price of whiteness: Jews, race, and American identity. (pp.11 -31). Princeton, NJ: Princeton University Press.

Goldstein, E. L. (2006c). What are We?; Jewishness Between Race and Religion. The price of whiteness: Jews, race, and American identity. (pp. 68 - 115). Princeton, NJ: Princeton University Press.

Goldstein, E. L. (2006d). World War II and the Transformation of Jewish Racial Identity. The price of whiteness: Jews, race, and American identity. (pp.189 - 208). Princeton, NJ: Princeton University Press.

Goldstein, E. L. (2006e). Epilogue, Jews, Whiteness, and “Tribalism” in Multicultural America. The price of whiteness: Jews, race, and American identity. (pp. 211 - 239). Princeton, NJ: Princeton University Press.

hooks, b. (2004). Understanding patriarchy (pp. 17-33). The will to Change: Men, Masculinity, and Love. New York: Atria Books. 
THE NEBRASKA EDUCATOR, VOLUME 6

Jupp, J. C. (2020). First-wave critical white studies. In Encyclopedia of Critical Whiteness Studies in Education (pp. 222-230). Brill Sense.

Jupp, J. C.; Berry, T. R.; Morales, A; Mason, A. M. (2018). What is to be done with curriculum and educational foundations' critical knowledges? Toward critical and decolonizing education sciences. Teaching Education, 29, 305-317.

Kohli, R. (2008). Breaking the cycle of racism in the classroom: Critical race reflections from future teachers of color. Teacher Education Quarterly, 35(4), 177-188.

Ladson-Billings, G. \& Tate, W. F. (1995). Toward a critical race theory of education. Teachers College Record, 97, 47-68.

Lewowicki, T. (1994). Janusz Korczak. Prospects, 24(1-2), 37-48. doi: 10.1007/bf02199005

Matias, C. (2016). Why do you make me hate myself: Re-teaching whiteness, abuse, and love in urban teacher education, Teaching Education, 27, 194-211.

McIntosh, P. (1988). White privilege male privilege: A personal account of coming to see correspondences through work in women's studies (Working Paper No. 189). Wellesley, MA: Wellesley Center for Research on Women.

Morales, A., Abrica, E., \& Harrera, S. (2019). The Mañana Complex: A Revelatory Narrative of White Innocence and Racial Disgust Toward Mexican American Children. The Urban Review. DOI: https://rdcu.be/bmtTu

Omi M. \& Winant, H. (2014). Racial Formations in the United States. Book overview. (p. 3-13).

Patel, L. (2016). Chapter 1: Educational research as a site of coloniality, (pp. 11-28). Decolonizing Educational Research. New York: Routledge.

Picower, B. (2009). The unexamined whiteness of teaching: How white teachers maintain and enact dominant racial ideologies. Race Ethnicity and Education, 12(2), 197-215. 


\section{THE NEBRASKA EDUCATOR, VOLUME 6}

Scheurich, J. J. \& Young, M. (1997). Coloring epistemologies: Are our research epistemologies racially biased? Educational Researcher, 26(4).4-16.

Schraub, D. (2019). White Jews: An intersectional approach. AJS Review, 43(2), 379-407. doi:10.1017/S0364009419000461

Smedley, A. (2007). The history of the idea of race... and why it matters. At Race, Human Variation and Disease; Consensus and Frontiers. Address conducted at the American Anthropological Association (AAA) Conference. Warrenton, Virginia.

Vucic, B. (2017). The colonization of childhood: The critical pedagogy of Janusz Korczak. Symbolic violence in socio-educational contexts, 161. 
THE NEBRASKA EDUCATOR, VOLUME 6

\section{Appendix}

Table 1: Dictionary of Races or Peoples (Washington, DC: Government Printing Office, 1911, pp. 1, 2, 5, 73)

A. Title page and introductory pages
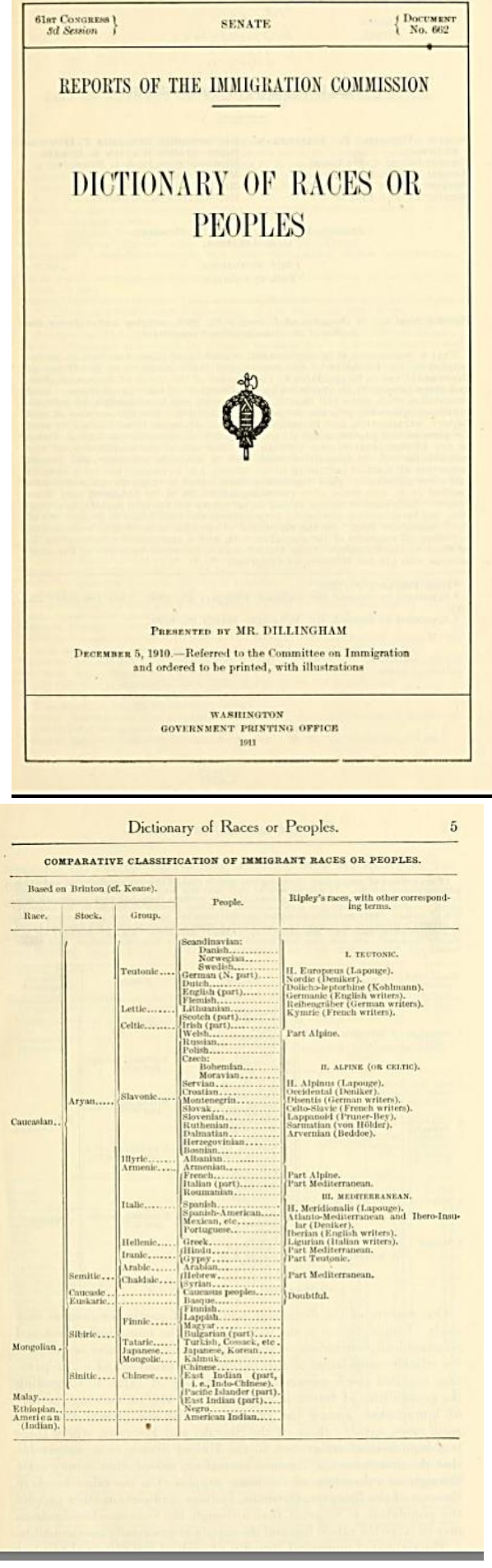

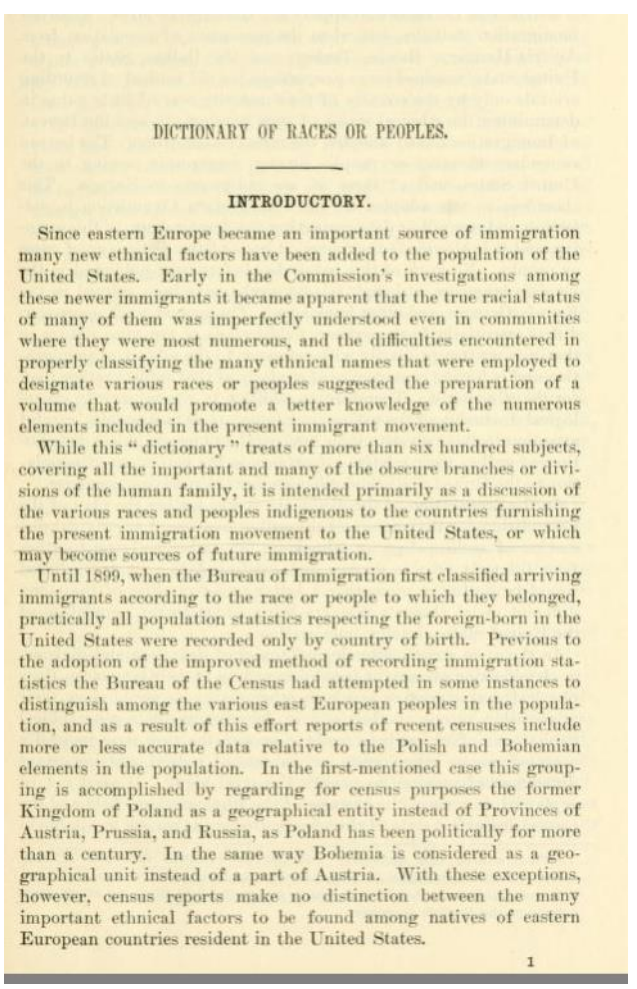

Since eastern Europe became an important source of immigration many new ethnical factors have been added to the population of the these newer immigrants it became apparent that the trae racial statn of many of them was imperfectly understood even in communities properly clascifying the many ethnieal names that were employed to

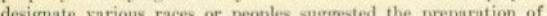
olume that would promote a better knowledme of the numerons European countries resident in the United States, 


\section{B. Entry for: Hebrew, Jewish, or Israelite (Note the brief entry for "Hawaiian or Sandwich Islander" as opposed to the complex history of the "Hebrews," which although not displayed in its entirety here, continues for three pages.}

\begin{tabular}{|c|c|}
\hline Dictionary of $\mathrm{R}$ & ces or Peoples. \\
\hline 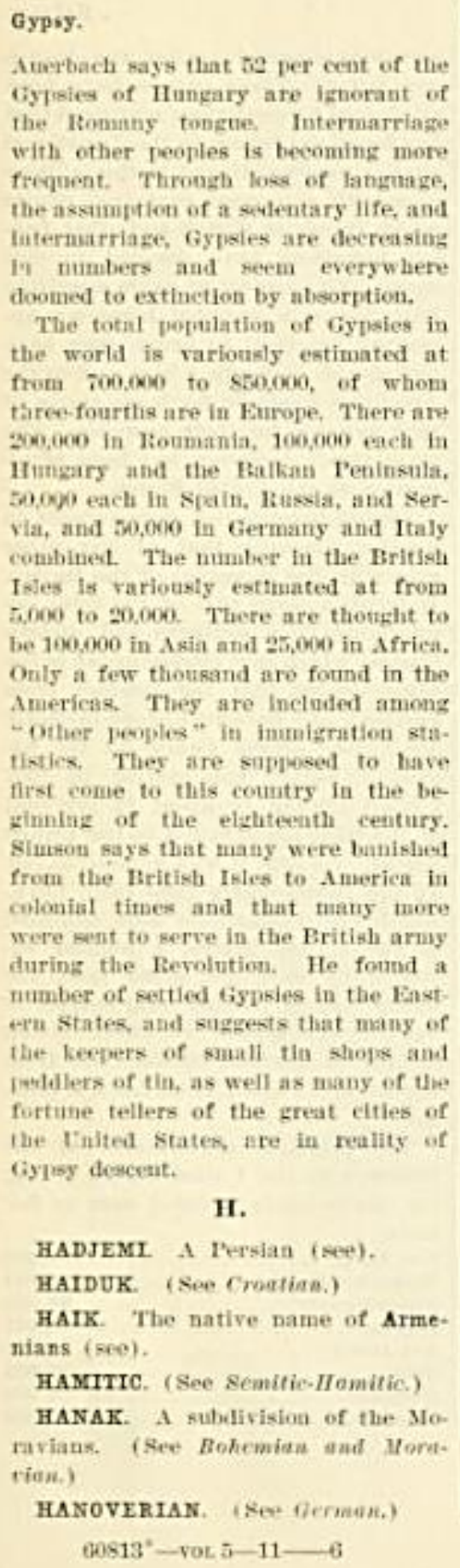 & 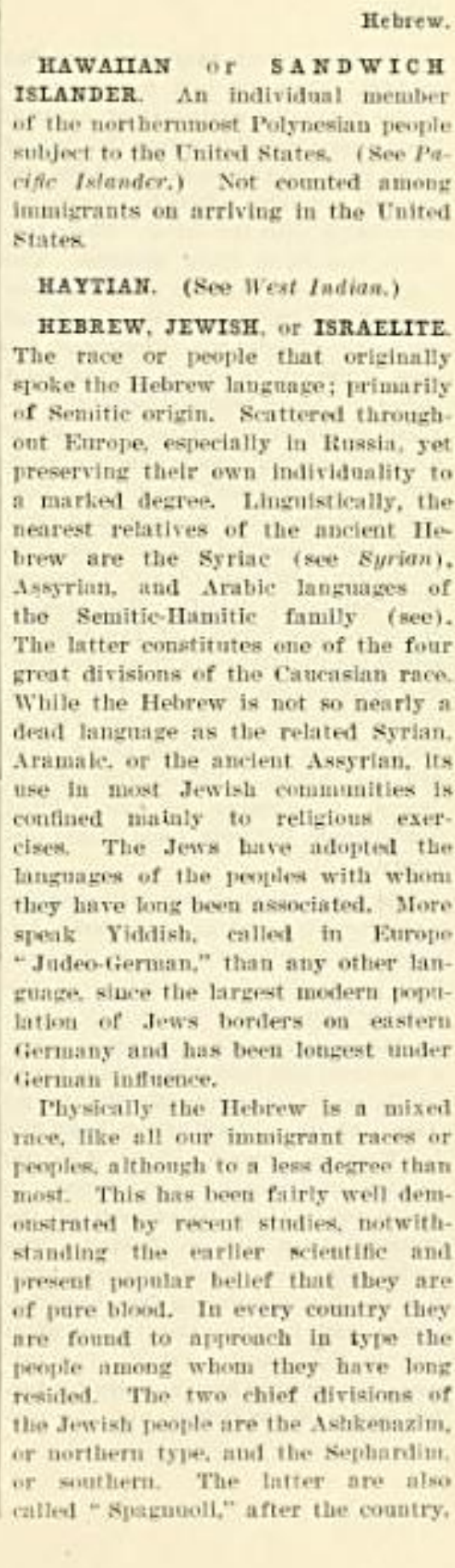 \\
\hline
\end{tabular}


THE NEBRASKA EDUCATOR, VOLUME 6

Table 2: Schraub (2019) Footnotes regarding Intersectionality of Whiteness and Jewishness

\begin{tabular}{|c|c|}
\hline \multicolumn{2}{|c|}{ Intersectionality of Whiteness and Jewishness } \\
\hline $\begin{array}{l}\text { a. Intersectionality of } \\
\text { Jews and } \\
\text { Whiteness }\end{array}$ & $\begin{array}{l}\text { Schraub's Footnotes reference the marginalization of Jews } \\
\text { throughout history and incongruencies of self and outward } \\
\text { identification: } \\
\text { The concept of the Jew as even being potentially White is of } \\
\text { relatively recent vintage. As racial discourse began to emerge } \\
\text { in Europe in the seventeenth century, the general (though not } \\
\text { universal) view was that Jews were at the very least racially } \\
\text { Other and perhaps even "Black." This went hand in hand with } \\
\text { Jewish subordination - Jewishness and Blackness reciprocated } \\
\text { and reinforced one another, as both served as markers of } \\
\text { disease, ugliness, and inferiority of all sorts. } \\
\text { (Schraub, 2019, p. 379-380) }\end{array}$ \\
\hline $\begin{array}{l}\text { b. Exclusion in } \\
\text { multicultural } \\
\text { discourse }\end{array}$ & $\begin{array}{l}\text { Schraub's Footnotes reference the following articles that reflect } \\
\text { discourse about Jews included/excluded in multicultural trends } \\
\text { See, e.g., Michael Galchinsky, "Glimpsing Golus in the Golden } \\
\text { Land: Jews and Multiculturalism in America," Judaism 43, no. } \\
4 \text { (1994): 360-68; Peter F. Langman, "Including Jews in } \\
\text { Multiculturalism," Journal of Multicultural Counseling \& } \\
\text { Development 23, no. } 4 \text { (1995): 226-36; Dan Ian Rubin, "Still } \\
\text { Wandering: The Exclusion of Jews from Issues of Social } \\
\text { Justice and Multicultural Thought," Multicultural Perspective } \\
\text { 15, no. } 4 \text { (2013): 213-19; Rubin, "Whiter Shade of Pale: } \\
\text { Making the Case for Jewish Presence in the Multicultural } \\
\text { Classroom," International Journal of Multicultural Education } \\
\text { 19, no. } 2 \text { (2017): 131-45. } \\
\text { (Schraub, 2019, p. 395) }\end{array}$ \\
\hline $\begin{array}{l}\text { c. Implication of } \\
\text { Jewish hegemonic } \\
\text { white privilege } \\
\text { and complicity }\end{array}$ & $\begin{array}{l}\text { Schraub's Footnotes reference explicit dismissal of aligning } \\
\text { Jewishness with "Otherness" } \\
\text { Rosa Pegueros recounts an experience where two mentions } \\
\text { of Jewishness on a listserv for contributors to Gloria E. } \\
\text { Anzaldúa and AnaLouise Keating's This Bridge We Call } \\
\text { Home: Visions for Radical Transformation (New York: } \\
\text { Routledge, 2002) sufficed to elicit complaints about Jewish } \\
\text { take-over of the space. Rosa Maria Pegueros, "Radical } \\
\text { Feminists-No Jews Need Apply,"Nashim } 8 \text { (2004): 174- } \\
\text { 80. Her experience coheres with my own. } \\
\text { (Schraub, 2019, p. 396) }\end{array}$ \\
\hline
\end{tabular}

